\title{
Quantitative study of the aerobic and anaerobic faecal flora in neonatal necrotising enterocolitis
}

\author{
C M M WESTRA-MEIJER, J E DEGENER, G DZOLJIC-DANILOVIC, M F MICHEL, AND \\ J W METTAU \\ Bacteriological Laboratory and Department of Paediatrics, Division of Neonatology, Rotterdam University \\ Hospital and Sophia Children's Hospital; Department of Clinical Microbiology and Antimicrobial Therapy, \\ Erasmus University, Rotterdam
}

SUMMARY Faeces from 24 neonates with proved necrotising enterocolitis (NEC), from 12 with clinically suspected NEC, and from 41 control infants were quantitatively cultured under aerobic and anaerobic conditions. An important difference in colonisation with Klebsiella was found between the NEC groups and the control group. Although the cause of NEC is unknown, colonisation with Klebsiella seems to increase the risk.

Necrotising enterocolitis (NEC) is found especially among preterm infants. Its principal clinical signs are distended abdomen, retention of food, and faecal blood loss. A typical radiological appearance is gas in the intestinal wall (pneumatosis intestinalis) and evidence suggests that this gas originates from bacteria. ${ }^{1}$ NEC is usually found in the terminal ileum, but it may extend to other parts of the intestine. It is associated with necrosis of the intestinal wall and in many cases leads to perforation and peritonitis. The incidence is usually reported as $1 \cdot 0-1 \cdot 5 / 1000$ live born infants, with a mortality of about $30 \%$. Published figures show that the incidence of NEC is higher and the prognosis more unfavourable in infants of low birthweight and young gestational age. ${ }^{2}$ Although NEC is an important problem in neonatal intensive care units (ICU), its cause is unknown. Several factors probably play a part in its aetiology-intestinal mucosal injury (caused by ischaemia, mechanical damage, or toxic substances), enteral feeding, and the presence of bacteria. $^{3}$ Whether certain bacterial species increase the risk of NEC is uncertain and a prospective controlled study of the faecal flora in NEC was undertaken to investigate this.

\section{Methods}

Patients. Three groups of patients were studied. Group 1 comprised 24 children in whom NEC was diagnosed radiologically or at operation, or both, or at necropsy. Group 2 comprised 12 children who showed clinical signs of NEC-distended abdomen, retention of food, and facael blood loss-but in whom the diagnosis could nct be proved. Group 3 comprised 41 control infants, matched for birthweight and gestational age, who were cared for in the same ICU during the study period. A subgroup of the controls was considered separately in the analysis of results. This was group 4, comprising 19 children whose faeces were cultured within 7 days before or after NEC was diagnosed in another child in the ICU.

Collection of material and culture. Between 20 September 1980 and 1 January 1982, faeces were collected from children who were at high risk from NEC. These were infants aged less than 1 month, born at a gestational age of less than 34 weeks, and with a birthweight of less than $2000 \mathrm{~g}$, who were admitted to the ICU. Faecal cultures were made on the first day of illness in groups 1 and 2 . In group 3 this was done on about day 10 , which is the usual age of onset of NEC.

After collection, a small amount of faeces was transferred to a bottle containing $3 \mathrm{ml}$ glycerol broth, stored at $4^{\circ} \mathrm{C}$, and used within 24 hours for quantitative cultures under aerobic and anaerobic conditions. ${ }^{4}$ The amount of faeces was determined by weighing the bottle of glycerol broth before and after adding the faeces.

After homogenisation, 10-fold serial dilutions in saline solution were prepared ${ }^{5}$ and $0.1 \mathrm{ml}$ of each dilution $\left(10^{-2}\right.$ to $\left.10^{-9}\right)$ spread on the following nutrient media: 5\% sheep blood agar (twice), MacConkey agar, Rogosa agar, and brucella agar (BBL) enriched with haemin and vitamin $\mathrm{K}$. Two variants of the latter nutrient medium were used: 1 to 
which kanamycin $(75 \mathrm{mg} / \mathrm{l})$ had been added, and 1 which also contained vancomycin $(7.5 \mathrm{mg} / \mathrm{l})$.

The sheep blood agar and the MacConkey medium were incubated aerobically at $37^{\circ} \mathrm{C}$ and read after 24 and 48 hours. The other media were incubated anaerobically at $37^{\circ} \mathrm{C}$ (Gas Pak system) and read after $\mathbf{4 8}$ to $\mathbf{7 2}$ hours and again after 7 days. Aerobic Gram negative cultures were worked up to species level (API $20 \mathrm{E}$ ). Staphylococci were divided into strains which did or did not produce coagulase. Streptococci were divided into enterococci and others. The anaerobic flora was identified by Gram staining and colony type. Anaerobic spore forming Gram positive rods (clostridia) were further typed with the aid of biochemical reactions and, when necessary, by gas chromatography. ${ }^{5}$ Isolations of Klebsiella were typed according to Riser et al. ${ }^{6}$

Toxin assay. After starting the culture the faecal samples were stored at $-70^{\circ} \mathrm{C}$. Later the cytotoxic effect of the filtered supernatants of these faecal samples was determined on human embryonic lung fibroblasts. Neutralisation tests were performed with antitoxin against Clostridium sordellii (Wellcome). ${ }^{7}$

Statistical analysis. Results were compared for the three groups of patients using Student's $t$ test and the Fisher exact test. A difference was described as significant when a two sided tail probability was $\mathbf{P}<0.05$.

\section{Results}

The 3 groups were compared for several clinical variables (Table 1). There were no important differences between the NEC and control groups, even for such factors as use of umbilical vessel catheters and the presence of a patent ductus arteriosus, which have been related to NEC by some authors. $^{89}$ An important difference was found only twice-in group 2, in which gestational age exceeded that in group 1 , and in which antibiotics were used less often than in group 3. In $99 \%$ of all patients the antibiotics given were a combination of amoxycillin and gentamicin. One child in group 1 received cephamandol instead of amoxycillin. In a few children the initial treatment was changed. Three children from the NEC and control groups were also treated with cloxacillin. One child from each group was given chloramphenicol. In group 3 amoxycillin was replaced by cephamandol in 3 children and by penicillin in 1.

The results of the faecal cultures are given in Table 2. The table lists only the most frequently isolated bacterial species as there were too few
Table 1 Clinical details of neonates with necrotising enterocolitis (NEC) (group 1), clinically suspected NEC (group 2), and controls (group 3)

\begin{tabular}{|c|c|c|c|}
\hline & $\begin{array}{l}\text { Group } 1 \\
(n=24)\end{array}$ & $\begin{array}{l}\text { Group } 2 \\
(n=12)\end{array}$ & $\begin{array}{l}\text { Group } 3 \\
(n=41)\end{array}$ \\
\hline $\begin{array}{l}\text { Male:female ratio } \\
\text { Birthweight (g) } \\
\text { (mean } \pm \text { SD) }\end{array}$ & $\begin{array}{c}1: 1 \\
1262 \pm 382\end{array}$ & $\begin{array}{c}1: 2 \\
1386 \pm 345\end{array}$ & $\begin{array}{r}1: 1 \cdot 05 \\
1329 \pm 288\end{array}$ \\
\hline $\begin{array}{l}\text { Gestational age (weeks), } \\
\text { (mean } \pm \text { SD) }\end{array}$ & $29 \cdot 4 \pm 2 \cdot 8$ & $31 \cdot 4 \pm 2 \cdot 7^{*}$ & $30 \cdot 3 \pm 2 \cdot 0$ \\
\hline $\begin{array}{l}\text { Age at faecal culture (days), } \\
\text { (mean } \pm \text { SD) }\end{array}$ & $12 \cdot 3 \pm 6 \cdot 9$ & $10 \cdot 8 \pm 6 \cdot 8$ & $11 \cdot 2 \pm 2 \cdot 6$ \\
\hline $\begin{array}{l}\text { Age at start of enteral feeding } \\
\text { (days), (mean } \pm \text { SD) }\end{array}$ & $2 \cdot 3 \pm 2 \cdot 1$ & $1 \cdot 9 \pm 1 \cdot 4$ & $1 \cdot 9 \pm 1 \cdot 3$ \\
\hline $\begin{array}{l}\text { No }(\%) \text { given antibiotic } \\
\text { medication } \ddagger\end{array}$ & $20(83)$ & $7(58) \dagger$ & $36(88)$ \\
\hline $\begin{array}{l}\text { No }(\%) \text { treated by umbilical } \\
\text { vessel catheter }\end{array}$ & $4(17)$ & $7(25)$ & $5(12)$ \\
\hline $\begin{array}{l}\text { No }(\%) \text { treated by } \\
\text { arterial line }\end{array}$ & $17(71)$ & $8(67)$ & $33(80)$ \\
\hline $\begin{array}{l}\text { No }(\%) \text { given exchange } \\
\text { transfusion }\end{array}$ & $1(4)$ & 2 (17) & $4(10)$ \\
\hline $\begin{array}{l}\text { No }(\%) \text { given } \\
\text { ventilatory support }\end{array}$ & $14(58)$ & 5 (42) & $21(51)$ \\
\hline $\begin{array}{l}\text { No }(\%) \text { with hyaline } \\
\text { membrane disease }\end{array}$ & 7 (29) & $3(25)$ & $16(39)$ \\
\hline $\begin{array}{l}\text { No }(\%) \text { with patent } \\
\text { ductus arteriosus }\end{array}$ & $9(38)$ & $5(42)$ & $12(30)$ \\
\hline
\end{tabular}

*Significant difference between group 1 and group $2(P<0.05)$ with Student's $t$ test; tsignificant difference between group 2 and group 3 $(P=0.04)$ with Fisher's exact test; †antimicrobial drugs given before or during collection of bacterial samples.

Table 2 Survey of bacterial species isolated from faeces of neonates with necrotising enterocolitis (NEC) (group 1), clinically suspected NEC (group 2), and controls (group 3). Results expressed as number (\%) of infants

\begin{tabular}{lrcc}
\hline & $\begin{array}{c}\text { Group 1 } \\
(n=24)\end{array}$ & $\begin{array}{l}\text { Group 2 } \\
(n=12)\end{array}$ & $\begin{array}{l}\text { Group } 3 \\
(n=41)\end{array}$ \\
\hline Gram negative aerobic & $22(92)$ & $9(75)$ & $24(59)^{*}$ \\
$\quad$ Escherichia coli & $8(33)$ & $3(25)$ & $12(29)$ \\
Enterobacter & $6(25)$ & $3(25)$ & $9(22)$ \\
Pseudomonas & $3(13)$ & $2(17)$ & $6(15)$ \\
Klebsiella & $17(71)$ & $7(58)$ & $15(37) \dagger$ \\
Gram positive aerobic & $17(71)$ & $9(75)$ & $36(88)$ \\
$\quad$ Enterococcus & $14(58)$ & $6(50)$ & $23(56)$ \\
Staphylococcus epidermidis & $13(54)$ & $7(58)$ & $25(61)$ \\
Gram negative anaerobic & $5(21)$ & $3(25)$ & $9(22)$ \\
$\quad$ Bacteroides & $4(17)$ & $2(17)$ & $8(20)$ \\
Gram positive anaerobic & $15(63)$ & $9(75)$ & $26(63)$ \\
Clostridium & $14(58)$ & $8(67)$ & $25(61)$ \\
\hline
\end{tabular}

*Significant difference between group 1 and group $3(P=0.005)$; tsignificant difference between group 1 and group $3(\mathrm{P}<0.01)$.

isolations of other species to permit statistical analysis. Table 2 shows that the only difference between group 1 and group 3 was in the frequency of isolation of aerobic Gram negative rods-in particular, Klebsiella. We found an important difference in colonisation with Klebsiella between groups 1 and 4 , but this difference just escaped significance $(P=0 \cdot 07)$. 


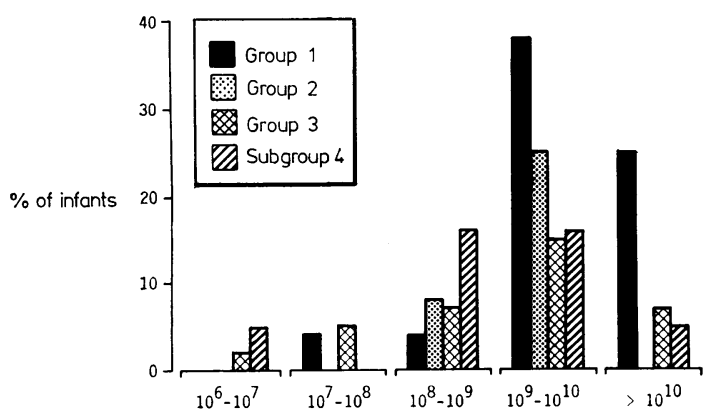

Fig. 1 Bacterial density of Klebsiella in faeces; percentage of infants in each group colonised with a certain number of organisms $/ \mathrm{g}$ faeces.

The density of aerobic Gram negative organisms in the faeces of neonates was generally very high, attaining values exceeding $10^{10} / \mathrm{g}$. The difference in colonisation with Klebsiella between groups 1 and 3 was most prominent at high bacterial densities (Fig. 1).

Table 3 shows how often the density of Klebsiella in the faeces exceeded the density of 1 of the other aerobic Gram negative bacterial species. Klebsiella was found significantly more often in group 1 than in groups 3 and 4.
Table 3 Number of faecal samples in which density of Klebsiella (number of organisms/g) exceeded that of other Gram negative aerobic species

\begin{tabular}{lllll}
\hline & $\begin{array}{l}\text { Group 1 } \\
(n=24)\end{array}$ & $\begin{array}{l}\text { Group 2 } \\
(n=12)\end{array}$ & $\begin{array}{l}\text { Group 3 } \\
(n=41)\end{array}$ & $\begin{array}{l}\text { Group 4 } \\
(n=19)\end{array}$ \\
\hline $\begin{array}{c}\text { No of samples } \\
\text { containing }\end{array}$ & 17 & 7 & 15 & 8 \\
$\begin{array}{c}\text { Klebsiella } \\
\begin{array}{c}\text { No of samples in } \\
\text { which Klebsiella } \\
\text { predominated }\end{array}\end{array}$ & 13 & 4 & 5 & 2 \\
\hline
\end{tabular}

Significant differences between group 1 and group $3(P=0.031)$ and between group 1 and group $4(P=0 \cdot 028)$.

Table 4 Clostridium species isolated from faeces of 77 neonates in the 3 groups

\begin{tabular}{llll}
\hline & $\begin{array}{l}\text { Group 1 } \\
(n=24)\end{array}$ & $\begin{array}{l}\text { Group 2 } \\
(n=12)\end{array}$ & $\begin{array}{l}\text { Group 3 } \\
(n=41)\end{array}$ \\
\hline $\begin{array}{l}\text { No of samples from which } \\
\text { clostridia were isolated }\end{array}$ & 14 & 8 & 25 \\
$\begin{array}{l}\text { Clostridium difficile } \\
\text { Clostridium perfringens }\end{array}$ & 12 & 8 & 19 \\
Clostridium butyricum & 3 & 2 & 5 \\
Clostridium paraputrificum & 3 & - & 1 \\
Others & 4 & 1 & 2 \\
\hline Total & 2 & - & 6 \\
\hline
\end{tabular}

* More than 1 species was isolated repeatedly from faeces of 1 patient.

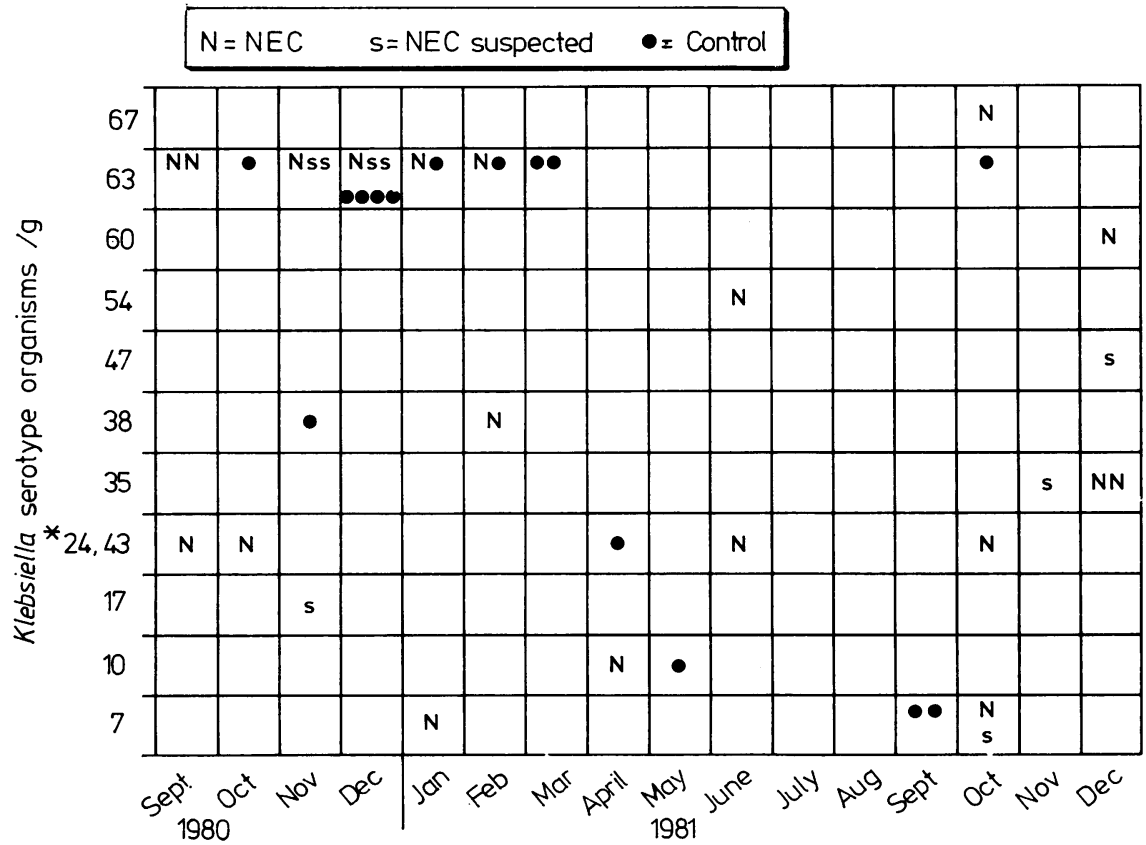

Fig. 2 Serotypes of Klebsiella strains isolated from faeces of patients with necrotising enterocolitis (NEC), patients clinically suspected of NEC, and control patients between September 1980 and January 1982.

* Owing to cross reactions it was impossible to establish whether the isolates were of serotype 24 or 43.

In 2 NEC patients and 1 clinically suspect child, 2 different serotypes of Kiebsiella were isolated. 


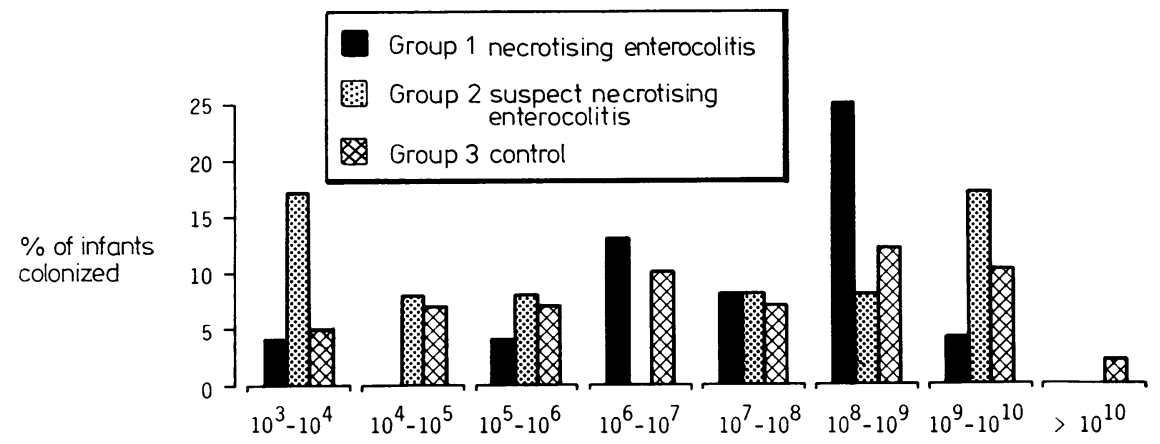

Fig. 3 Number of clostridial organisms/g faeces.

Table 5 Percentage frequency of isolation of bacterial species from faeces of neonates with necrotising enterocolitis (NEC) and a control group. Comparison of 3 studies

\begin{tabular}{|c|c|c|c|c|c|c|c|c|c|}
\hline & \multicolumn{3}{|c|}{ Frantz et al. 10} & \multicolumn{3}{|c|}{ Bell et al. ${ }^{11}$} & \multicolumn{3}{|c|}{ This study } \\
\hline & $\begin{array}{l}N E C \\
(n=51)\end{array}$ & $\begin{array}{l}\text { Control } \\
(n=50)\end{array}$ & $P$ value & $\begin{array}{l}N E C \\
(n=27)\end{array}$ & $\begin{array}{l}\text { Control } \\
(n=41)\end{array}$ & $P$ value & $\begin{array}{l}N E C \\
(n=24)\end{array}$ & $\begin{array}{l}\text { Control } \\
(n=41)\end{array}$ & $P$ value \\
\hline Gram negative aerobic & & & & 82 & 51 & $<0.01$ & 92 & 59 & 0.005 \\
\hline Gram positive aerobic & & & & 74 & 71 & & 71 & 88 & \\
\hline Gram negative anaerobic & & & & 30 & 27 & & 21 & 22 & \\
\hline Gram positive anaerobic & & & & 7 & 2 & & 63 & 63 & \\
\hline Klebsiella & 38 & 16 & 0.03 & 58 & 17 & $<0.005$ & 71 & 37 & 0.01 \\
\hline Escherichia coli & 36 & 22 & & 50 & 29 & $<0.05$ & 33 & 29 & \\
\hline Staphylococcus epidermidis & 30 & 30 & & 54 & 63 & & 54 & 61 & \\
\hline Enterococcus & 10 & 6 & & & & & 58 & 56 & \\
\hline$\alpha$-Streptococcus & 24 & 20 & & & & & & & \\
\hline Group D haemolytic streptococcus & & & & 27 & 17 & & & & \\
\hline Pseudomonas & 8 & 2 & & & & & 13 & 15 & \\
\hline Candida & 16 & 18 & & & & & 4 & 17 & \\
\hline 'Sterile' & 14 & 24 & & & & & & & \\
\hline Bacteroides & & & & & & & 17 & 20 & \\
\hline Bacteroides fragilis & & & & 12 & 10 & & & & \\
\hline Clostridium & & & & & & & 58 & 61 & \\
\hline
\end{tabular}

Strains were typed to establish whether a particular serotype of Klebsiella was predominant during the observation period. Fig. 2 shows an epidemic increase in type 63 during September 1980 to March 1981 , but since the epidemic affected children from all the study groups this finding warrants no conclusion about a correlation between a particular serotype and NEC.

Because several species of Clostridium have been associated with NEC in the past few years, this group of bacteria was given special attention. No difference in colonisation with clostridia was found between the groups of infants (Fig. 3) even after classification by species (Table 4). Clostridium difficile toxin was found in 49 of the 77 children tested, but no intergroup differences were found; nor were there differences in the toxin titres. In each of the 20 cases with a toxin titre exceeding $1 / 100$, C. difficile was isolated from the faeces.

\section{Discussion}

The cause of NEC is unknown and the role of bacteria in its pathogenesis is probably secondary. Our study focused on whether certain bacterial species are more common in children with NEC. Older, mostly retrospective, studies focused attention on the role of aerobic Gram negative rods because positive blood cultures with these bacterial species were often found in patients with NEC. Prospective controlled studies of the bacterial flora in NEC were undertaken by Frantz et al. ${ }^{10}$ and Bell et al. ${ }^{11}$ The results of these studies and our results are summarised in Table 5. An important difference in colonisation with Klebsiella was always found between the NEC group and the control group.

Bell et al.,11 who considered the epidemiology in some detail, found a less pronounced difference in colonisation with Escherichia coli. To establish the 
relation between colonisation with a particular bacterial flora and the development of NEC, they performed a prospective study of the bacterial flora in children in the same ICU during 3 periods of 3 months each. They found the highest incidence $(4.7 \%)$ during the first period, when $E$. coli and Klebsiella accounted for $82 \%$ and $88 \%$, respectively, of the Enterobacteriaceae isolated from the stomach and from the faeces. These percentages decreased to $11 \%$ and $47 \%$ respectively during the second period (during which no NEC was observed), and increased again to $55 \%$ and $56 \%$ during the third period, when the incidence of NEC increased to $4.4 \%$. Proteus mirabilis was predominant during the second period. The authors concluded that the variation in the incidence of NEC correlates with the predominant bacterial flora in a particular ICU. This agrees with the observation of Stanley et al.,12 who found that a decrease in the incidence of NEC coincided with a change in the bacterial flora in an ICU in which Serratia superseded the previously predominant Klebsiella.

If we confine our analysis of the observed incidences of colonisation by Klebsiella to the subgroup of controls (group 4) whose faeces were cultured within 7 days before or after a diagnosis of NEC in another child, the difference between the NEC group and the control group decreases. This suggests that NEC occurred more frequently in the ICU during a period when Klebsiella was prevalent and appears to corroborate the conclusions of Bell et al. ${ }^{11}$ and Stanley et al. ${ }^{12}$ We did not study the bacterial fiora in all children in the ICU during the period of observation, however, and consequently have no comprehensive data on the degree of colonisation. We have meanwhile started a follow up study that does include all children, and this should enable us to examine the epidemiological relation between the occurrence of NEC and colonisation with Klebsiella.

In recent years the postulate that clostridia have a role in the pathogenesis of NEC has received much attention in published reports, and $C$. perfringens, ${ }^{13}$ $C$. butyricum, ${ }^{14}$ and $C$. difficile ${ }^{15}$ have been specifically mentioned. Several investigators have shown, however, that these clostridia should be regarded as normal faecal flora in neonates ${ }^{16-18}$ and that the production of toxins by $C$. difficile is normal in the first year of life. ${ }^{1920} \mathrm{We}$, too, failed to find differences in colonisation with clostridia or in C.difficile toxin production between the different groups studied.

\section{Conclusion}

Our findings suggest that colonisation with Klebsiella may increase the risk of NEC. Attempts might be made to protect infants in an ICU whose low birthweight further increases this risk. Isolation, selective decontamination, or prophylactic oral antibiotics may merit consideration in this respect, but only the latter method has been studied clinically. Prophylaxis by oral aminoglycosides was reported as successful by some authors ${ }^{21} 22$ and as unsuccessful by others. ${ }^{23}{ }^{24}$ In view of the possible development of resistance, prophylactic measures of this sort should be regarded with considerable reservation and should perhaps be confined to periods in which the prevalence of colonisation with Klebsiella in a ICU is high. This does imply, however, that the bacterial flora in children in an ICU must be constantly monitored.

We thank H J A Schouten, Department of Biostatistics, Erasmus University, Rotterdam, for statistical advice; J G van Oorschot for serotyping the Klebsiella isolates; Linda P C Harkes for typing the manuscript.

\section{References}

1 Engel RR, Virnig NL, Hunt CE, Levitt MD. Origin of mural gas in necrotizing enterocolitis (abstract). Pediatr Res 1973; 7: 292.

2 Stoll BJ, Kanto WP, Jr, Glass RI, Nahmias AJ, Brann AW. Epidemiology of necrotizing enterocolitis: a case control study. J Pediatr 1980; 96: 447-51.

${ }^{3}$ Santulli TV, Schullinger JN, Heird WC, et al. Acute necrotizing enterocolitis in infancy: a review of 64 cases. Pediatrics 1975; 55 : 376-87.

4 Crowther JS. Transport and storage of faeces for bacteriological examination. J Appl Bacteriol 1971 ; 34: 477-83.

5 Holdeman LV, Cato EP, Moore WEC. Anaerobe laboratory manual. 4th ed. Blacksburg, Virginia: Virginia Polytechnic Institute and State University Anaerobe Laboratory, 1977: 79-106.

- Riser E, Noone P, Poulton TA. A new serotyping method for Klebsiella species: development of the technique. J Clin Pathol 1976; 29: 296-304.

7 Larson HE, Price AB. Pseudomembranous colitis: presence of clostridial toxin. Lancet 1977; ii: 1312-4.

8 Bunton GL, Durbin GM, McIntosh N, et al. Necrotizing enterocolitis. Controlled study of 3 years' experience in a neonatal intensive care unit. Arch Dis Child 1977; 52: $772-7$.

9 Ryder RW, Shelton JD, Guinan ME, and the Committee on Necrotizing Enterocolitis. Necrotizing enterocolitis. A prospective multicenter investigation. Am J Epidemiol 1980; 112: 113-23.

10 Frantz ID, L'Heureux P, Engel RR, Hunt CE. Necrotizing enterocolitis. J Pediatr 1975; 86: 259-63.

11 Bell MJ, Shackelford P, Feigin RD, Ternberg JL, Brotherton T. Epidemiologic and bacteriologic evaluation of neonatal necrotizing enterocolitis. J Pediatr Surg 1979; 14: $1-4$.

12 Stanley MD, Null DM, Jr, deLemos RA. Relationship between intestinal colonization with specific bacteria and the development of necrotizing enterocolitis (abstract). Pediatr Res 1977; 11 : 543.

13 Kliegman RM, Fanaroff AA, Izant R, Speck WT. Clostridia as pathogens in neonatal necrotizing enterocolitis. J Pediatr 1979; 95 : 287-9. 
14 Howard FM, Bradley JM, Flynn DM, Noone P, Szawatkowski M. Outbreak of necrotising enterocolitis caused by Clostridium butyricum. Lancet 1977; ii: 1099-102.

15 Cashore WJ, Peter G, Lauermann M, Stonestreet BS, $\mathrm{Oh}$ W. Clostridia colonization and clostridial toxin in neonatal necrotizing enterocolitis. J Pediatr 1981; 98: 308-11.

16 Kindley AD, Roberts PJ, Tulloch WH. Letter: Neonatal necrotising enterocolitis. Lancet 1977; i: 649.

17 Kelsey MC, Vince AJ. Letter: Clostridia in neonatal faeces. Lancet 1979 ; ii: 100.

18 Smith MF, Borriello SP, Clayden GS, Casewell MW. Clinical and bacteriological findings in necrotising enterocolitis: a controlled study. Journal of Infection $1980 ; 2: 23-31$.

19 Rietra PJGM, Slaterus KW, Zanen HC, Meuwissen SGM. Letter: Clostridial toxin in faecal of healthy infants. Lancet 1978; ii: 319.

20 Cooperstock MS. Letter: Clostridium difficile, enterocolitis, and Hirschsprung's disease. Lancet 1982; i: 800.

21 Egan EA, Mantilla G, Nelson RM, Eitzman DV.
A prospective controlled trial of oral kanamycin in the prevention of neonatal necrotizing enterocolitis. J Pediatr 1976; 89: 467-70.

22 Grylack LJ, Scanlon JW. Oral gentamicin therapy in the prevention of neonatal necrotizing enterocolitis. Am J Dis Child 1978; 132: 1192-4.

23 Rowley MP, Dahlenburg GW. Letter: Gentamicin in prophylaxis of neonatal necrotising enterocolitis. Lancet 1978; ii: 532.

24 Boyle R, Nelson JS, Stonestreet BS, Peter G, Oh W. Alterations in stool flora resulting from oral kanamycin prophylaxis of necrotizing enterocolitis. $J$ Pediatr 1978; 93: 857-61.

Correspondence to C M M Westra-Meijer, Bacteriological Laboratory, University Hospital Rotterdam; Dr Molewaterplein, 40, 3015 GD Rotterdam, The Netherlands.

Received 22 February 1983

British Paediatric Association

Annual meetings

1984 10-14 April York University

1985 16-20 April York University

1986 15-19 April York University

1987 7-11 April York University 